\title{
Building Fun Teaching and Learning Process through Simple Science Experiment Activity to Foster Young Learners' Participation and English Vocabulary Identification
}

\author{
Nia Roistika \\ STKIP PGRI Tulungagung, East Java, Indonesia \\ Corresponding e-mail: nia.roistika@gmail.com
}

\begin{abstract}
This study was classified into classroom action research (CAR) which carried out the implementation of Simple Science Experiment during teaching and learning process at Kindergarten students' at Frances Pre-school Tulungagung to overcome the students' difficulties on identifying English vocabulary. In accordance to the preliminary study results showed that (1) the students had low participation during teaching and learning process (2) the students had difficulty in identifying and memorizing English vocabulary. Consequently, the criteria of success were aimed to the stated problems above. The results of the research proved that applying Simple Science Experiment during teaching and learning process in Kindergarten level was able to upgrade the students' participation and English vocabulary identification. The Simple Science Experiment supported the Kindergarten students to get involved actively during teaching and learning process and created mostly students gaining better ability in English vocabulary identification.
\end{abstract}

Keywords: Simple Science Experiment, participation, English vocabulary identification, classroom action research.

\section{INTRODUCTION}

English nowadays has been introduced to the early age from four up to six years old young learner. It is caused by the popularity that young learner are fast learners better than adults (Brown, 2007). The year's age from birth through five are the time of amazing development and transformation. Thus, in Frances pre-school, Tulungagung itself where the research is conducted, this pre-school uses English as the means of communication during class. Since, they believe that young learners gain a new language effortless.

Conducting a class of young learners needs assorted activities in order to help them gaining many experiences, fresh knowledge, and new challenge during spending the school time. Since this school applies English as a means of communication in class, each activities during teaching and learning process is carried out in English. Moreover, McKay and Guse (2007) stated that enabling children to think and communicate in English gives them several benefits such as acquiring new language, improving strategies to convey meanings, ideas, opinions to others, and finally they are capable to apply this new knowledge to new situations. Besides, providing varied activities gives children a chance to reflect on and learn latest things as they take a part actively in the activities during teaching and learning process.

Next, during teaching and learning process, participation promotes an important element in order to assist a language learner achieving goal in language learning. Therefore, a teacher should keep the classroom atmosphere relaxing, fun, and challenging since classroom situation takes an important role in increasing students' participation in learning English. To be successfully in teaching young learner, a teacher requires particular skills and instincts (Brown, 2007). Teacher needs to be very creative to help young learner involved actively during teaching and learning process. A good English teacher has their ability in comprehending a certain strategy finally bringing it to be applied in classroom situation as well (Brown, 2007). 
Vocabulary itself is one of the language components that is necessary to be mastered by English learners. Moreover, Troike (2006) stated that vocabulary is language component that is crucial to all level of English learners. Knowing assorted English vocabulary brings valuable effect to learners. They are easy to recognize variety of English words. In addition, according to Fachrurrazy (2010), the goal of teaching vocabulary should cover product and process. Product shows the mastery of vocabulary items of a learner while process explains the learners' capability to discover a certain foreign word then enlarge the mastery of their vocabulary.

The preliminary study during teaching English process in Frances pre-school, Tulungagung was discovered several problems such as low participation of students' of young learners during teaching and learning process and difficulties in identifying and memorizing English vocabulary.

The first problem found during preliminary study was the low participation during teaching and learning process. In this case students of young learners still had lack of attention to the class. They just sat on the chair, saw the pictures and did not do anything in spite of seeing and listening. In addition, they talked to their friends, played by themselves and sometimes teacher needed to call their names in order to make them quiet. This kind of situation made the class uncontrolled. Thus, they did not participate actively during the class. As a matter of fact, young learner needed to stimulate all their five senses. However, during the preliminary study, it was detected that they utilize more on their eyes and ear during the class since the class is chiefly on the use of pictures. Therefore, they got bored easily and finally they had low participation during teaching and learning process.

Next, the students had difficulties in identifying and memorizing English vocabulary. The ability of students of young learner is still far from satisfaction and needed improvement. Students were mostly hard to identify and memorize vocabulary in English. They frequently responded and replied a certain English vocabulary in their native language. For example, when teacher showed additionally, some limitations which are frequently found during teaching and learning English in this pre-school was identified. Mostly, the class was conducted in conventional ways such as memorizing, questionanswer, or lecturing. In this case the use of pictures was mostly applied in presenting the material. As the result, using pictures was not too attractive for the young learners.
In accordance to the risen problems above, some interesting strategies are needed to present the material. It is important for the teacher to select a proper strategy which are suitable to the students' characteristics and also to the presented materials.

Additionally, doing a classroom action research in order to offer a strategy to foster the students' participation and vocabulary identification was necessitated to be done. This gap situation was proposed to be solved by the use of simple science experiment.

The researcher tries to use simple science experiment where the students directly take a part actively of simple experiments during the class. It means that the students directly touch the equipment's and make the experiments by themselves at the same time. This strategy allows the students of young learners experiencing directly by seeing, hearing, touching and doing as stated by Fachrurrazzy, (2010) "involve five senses: see, hear, touch, experience" during the activities in the classroom. Moreover, this strategy is categorized into science project that helps the students of young learners absorb the language and learn words in order to support them to get meaningful language (Brown:2007).

\section{METHOD}

This research is conducted by classroom action research. This kind of research aims at finding out learning teaching strategies that is suitable to learners' style and strategies in learning English (Latief : 2012). In fact, this research was conducted in a classroom setting aiming to foster the young learners' participation and English vocabulary identification. While the research subjects were the young learners who aged around five to six years old.

In accordance to the grown problems like the low participation and hard identification to English words of young learners and the goal of the research as stated above, Classroom Action Research (CAR) is chosen as the design of this research. Furthermore, the researcher designed planning, actuating, observing (gathering and analyzing the data), and reflecting (making conclusions and research report).

\subsection{Planning}

The researcher plans the teaching strategy that will be applied in the research. The selected strategy was simple science experiment, the steps of the strategy in the classroom as follows: find and prepare the stuff that you want to present during the experiment 
in the class according to the topic given for example teacher needs to introduce the students about air you may prepare some balloons and a pump. Then, explain the students by introducing and mentioning the arranged stuff in target language. Next, teacher needs to clarify the instruction to the students step by step in conducting a science experiment. The last, teacher and the students may start the experiment together in fun way.

\subsubsection{Designing the Lesson Plan}

The lesson plan focused on the use of simple science experiment in the classroom to resolve the young learners' problems in low participation during class and hard recognition of English words. The topics discussed in this cycle are related to air and water.

Simple science experiment itself was inspired by several theories related to the principal of conducting a class of young learners. As stated by Fachrurrazy (2010), the young learners need to involve all his five senses included seeing, hearing, touching, and experiencing. Next, Brown (2007) proposed that children require to use all five senses enliven. Simple science experiment support students of young learners to cover visual and auditory as well.

The steps in conducting this strategy include explaining, informing, demonstrating and doing. These steps are able to include the children's five senses. Thus, children are able to involve the activities of seeing, hearing, touching, and doing. This teaching activity is simple for every teacher to be able to apply it in his/her class.

\subsubsection{Criteria of Success}

The criteria of success applied in this research is that students of young learners are able to identify vocabulary in fully simple English. It means that they reached the excellent grade. Moreover, conducted class using by simple science experiment creates the atmosphere of teaching and learning process is getting better such as giving fun and joyful learning experience (Latief, 2012), improving children's participation during the class.

\subsection{Implementation}

When all preparations are well-prepared, the researcher implemented the designed activities by using simple science experiment. The subject of the research is five to six aged young learners, Frances pre-school, Tulungagung.
In this step the strategy is implemented. During the implementation of simple science experiment the researcher demonstrated some simple science experiments in order to deliver some vocabulary to children. While the procedures of conducting simple science experiment as the given topic is air, are as follows:

1. Explain to the class that you are going to learn new vocabulary the names of thing that are moved by air and not moved by air. (The topic depends on your class)

2. Inform the children that you will teach them reciting about air. The recital is describe below: Air is unseen

I cannot touch air

But I can feel it

Now feel it (blow a friend's ear)

3. Then tell the children that you will introduce and mention things that are moved by air such as tissue, paper, leaf, plastic, ping pong ball so these stuff are classified as light. Then introduced the class table, chair, fork, spoon and these things are categorized as heavy. Make sure teacher repeats each of presented vocabulary.

4. Inform the children the function of air in our life both of breathing and moving something.

5. Demonstrate by blowing straw to show that air is useful for moving something.

6. Finally, children will do it by themselves by blowing the prepared stuff.

The next procedures of conducting simple science experiment in delivering topic entitled water are described below:

1. Start your class by singing together

2. Explain to the class that you are going to learn new vocabulary such as a bottle, a jar, a bowl and a cup.

3. Inform the children the characteristics and function of water.

4. Teacher demonstrates the characteristics of water by pouring it into a bottle, a jar, a bowl and a cup. Then teacher demonstrates watering flower to show the function of water.

5. Children do the demonstration as the teacher did before.

6. Children do demonstration while reciting as follows: "I put some water into a bottle, it will be like a bottle." "I put some water into a jar, it will be like a jar".

During the implementation of the action plan, the researcher was assisted by collaborator who at the same time acted as the observer in the teaching and learning process in the class in order to observe 
whether the strategy is able to overcome the classroom problems (Latief, 2012). During the process, a collaborator held video recording, field notes and documentation.

\subsection{Observation}

\subsubsection{Data and Source of Data}

The data were in the form of qualitative data, recording and documentation. The data were gained from the students and the collaborating teacher.

\subsubsection{Instrument and Strategies for Data Collection}

To collect the required data, the researcher utilized video recording, a field-note, documentation and a test. The video recording was used to record all the activities both of teacher and the students of young learners. The field notes were used regularly to take notes and record the information about the event, dates, and persons involved during the teaching and learning process. Next, the documentation itself was used to record all the activities in the forms of photos. The last was a test used to get the young learners' achievement on vocabulary identification related to the topic given.

\subsection{Reflection}

This section concerns with the activity to examine the implementation of the actions during the cycle that was gained through the result of observations. It covers the discussion of how far the suggested strategy answers the existed problems and the factors that might cause the ineffective strategy applied.

During the research, the researcher did the reflection in the activities of learning process and the effect of the activities as well as toward the progress of young learners' participation and vocabulary identification. The data gained then checked with the criteria of success to identify whether the data have reached the criteria or not. The reflection itself is important as the basic consideration to revise the model to be used in the upcoming cycle to obtain better result of learning or the researcher should stop since the result have met the criteria of success.

\section{RESULTS}

\subsection{The Students' Participation}

In accordance to the result of the research, all students of young learners involve actively in the teaching and learning process of vocabulary identification. To obtain the data, the researcher used video recording and field note to show the students' participation during the class. The children did and experienced the science experiment by themselves. They touched the equipment's used and acted as instructed by the teacher. In addition, they feel fun, enjoyable and joyful during teaching and learning process.

To gain the data of students' of young learners participations, the researcher used video recording that shown the activities of teacher and students during the implementation of simple science experiment in the class. Moreover, field note also supported the data of students' participation. Those two instruments of collecting data indicated that students' of young learners involved actively during the implementation of simple science experiment.

The video recording and field note gave information that the students felt fun, cheerful during the class of simple science experiment. They took a part directly and actively during the process of implemented strategy.

Even though, they loss of control because they had to pay attention to the instruction before they directly did the science experiment by themselves.

\subsubsection{Test}

The test was given after the students of young learners did simple science experiment. The test was in the form of students' paper on identifying the word in English related to the topic that was given during the applied strategy in the classroom.

Additionally, all the given words were mentioned in English then the students needed to find on the paper test. The result of the students' tests have met the criteria of success. Most of the students are able to identify by mentioning the new vocabularies in fully English. Before the implemented strategy, children frequently responded to teacher's question in native language, sometimes they also replied it in half native language and half English. On the other hand, the proposed strategy of simple science experiment was able to answer the existed problem like the low participation of children in teaching and learning English and the hard identification of vocabulary in English. 
The criteria of success have met the criteria at the same time. Each student was able to identify vocabulary in fully simple English. Thus, the students got the excellent grade.

The weakness was what the collaborator noted in field-note that the students who did not take a part tend to play with their friends. And there was a phase that they had to pay attention to the teacher's instruction first and this made them got bored easily.

\section{CONCLUSIONS}

The results above indicate that the students have improved their ability in identifying vocabulary in fully simple English and their participation during the class was increased as well. Thus, the applied strategy in resolving the problems on identifying vocabulary and students' of young learners worked well. It clearly indicated that students took a part actively in the implementation of simple science experiment specifically during the science experiment which was done by the students themselves.

Then, students were able to identify vocabulary in fully simple English. This indicated that students got the excellent grade and brought them to the criteria of success.

\section{ACKNOWLEDGEMENTS}

First of all, I send my big thank to Allah swt for the blessing thus I am able to complete this paper well. Next, I wish to acknowledge the financial support of STKIP PGRI Tulungagung for allowing me to have this international seminar. Then, I deliver my admiration to my family for their support and love. Finally, my big appreciation goes to all my colleagues for their support and help for me to finish this paper.

\section{REFERENCES}

Brown H.Douglas, (2007). Teaching by Principles: An Interactive Approach to Language Pedagogy $\left(3^{\text {rd }}\right.$ ed). White Plains, NY: Pearson Education

Fachrurrazy. (2010) Teaching English as a Foreign Language for Teachers in Indonesia (2010 ed). Malang, IND: The State University of Malang. McKay Penny., and Jenny Guse. (2007). FiveMinute Activities for Young Learners. United States of America, NY: Cambridge University Press.
Latief Mohammad Adnan. (2012). Research Methods on Language Learning An Introduction. Malang, IND: UM Press.

Troike Muriel-Saville. (2006). Introducing Second Language Acquisition. United States of America, NY: Cambridge University Press 